\title{
The importance of understanding individual differences in
}

\section{Down syndrome [version 1; peer review: 2 approved]}

\author{
Annette Karmiloff-Smith 1,2, Tamara Al-Janabi2,3, Hana D'Souza1,2, Jurgen Groet 2,4, \\ Esha Massand1,2, Kin Mok2,5,6, Carla Startin2,3, Elizabeth Fisher2,7, John Hardy2,5, \\ Dean Nizetic $2,4,8$, Victor Tybulewicz 2,9,10, Andre Strydom ${ }^{2,3}$
}

\footnotetext{
${ }^{1}$ Centre for Brain \& Cognitive Development, Birkbeck University of London, London, WC1E 7HX, UK

${ }^{2}$ The London Down Syndrome Consortium (LonDownS), University College London, London, UK

${ }^{3}$ Division of Psychiatry, University College London, London, W1T 7NF, UK

${ }^{4}$ The Blizard Institute, Barts \& The London School of Medicine, Queen Mary University of London, London, E1 2AT, UK

${ }^{5}$ Department of Molecular Neuroscience, University College London Institute of Neurology, London, WC1N 3BG, UK

${ }^{6}$ Division of Life Science, Hong Kong University of Science and Technology, Hong Kong SAR, China

${ }^{7}$ Department of Neurodegenerative Disease, Institute of Neurology, London, WC1N 3BG, UK

${ }^{8}$ Lee Kong Chian School of Medicine, Nanyang Technological University, Biopolis, 138673, Singapore

${ }^{9}$ Francis Crick Institute, London, NW7 1AA, UK

${ }^{10}$ Department of Medicine, Imperial College London, London, W12 0NN, UK
}

V1 First published: 23 Mar 2016, 5(F1000 Faculty Rev):389

https://doi.org/10.12688/f1000research.7506.1

Latest published: 23 Mar 2016, 5(F1000 Faculty Rev):389

https://doi.org/10.12688/f1000research.7506.1

\section{Abstract}

In this article, we first present a summary of the general assumptions about Down syndrome (DS) still to be found in the literature. We go on to show how new research has modified these assumptions, pointing to a wide range of individual differences at every level of description. We argue that, in the context of significant increases in DS life expectancy, a focus on individual differences in trisomy 21 at all levels-genetic, cellular, neural, cognitive, behavioral, and environmental-constitutes one of the best approaches for understanding genotype/phenotype relations in DS and for exploring risk and protective factors for Alzheimer's disease in this high-risk population.

\section{Keywords}

Down syndrome , Alzheimer's disease , neurodevelopmental disorder , trisomy 21 ,

\section{Open Peer Review \\ Approval Status \\ 1 \\ 2 \\ version 1 \\ 23 Mar 2016 \\ Faculty Reviews are review articles written by the prestigious Members of Faculty Opinions. The articles are commissioned and peer reviewed before publication to ensure that the final, published version is comprehensive and accessible. The reviewers who approved the final version are listed with their names and affiliations.}

1. Roger H. Reeves, Johns Hopkins University, Baltimore, USA

2. Jennifer Wishart, University of Edinburgh, Edinburgh, UK

Any comments on the article can be found at the 
end of the article.

Corresponding author: Annette Karmiloff-Smith (a.karmiloff-smith@bbk.ac.uk)

Competing interests: All the authors declare that the writing of this paper took place in the absence of any commercial or financial relationships that could be construed as a potential conflict of interest.

Grant information: All the authors of this paper are funded by Wellcome Trust Strategic Grant No. 098330/Z/12/Z conferred upon The LonDownS Consortium UK. Dean Nizetic is funded also by the Lee Kong Chian School of Medicine, Nanyang Technological UniversitySingapore Start-up Grant.

The funders had no role in study design, data collection and analysis, decision to publish, or preparation of the manuscript.

Copyright: @ 2016 Karmiloff-Smith A et al. This is an open access article distributed under the terms of the Creative Commons Attribution License, which permits unrestricted use, distribution, and reproduction in any medium, provided the original work is properly cited. The author(s) is/are employees of the US Government and therefore domestic copyright protection in USA does not apply to this work. The work may be protected under the copyright laws of other jurisdictions when used in those jurisdictions.

How to cite this article: Karmiloff-Smith A, Al-Janabi T, D'Souza $\mathrm{H}$ et al. The importance of understanding individual differences in Down syndrome [version 1; peer review: 2 approved] F1000Research 2016, 5(F1000 Faculty Rev):389 https://doi.org/10.12688/f1000research.7506.1

First published: 23 Mar 2016, 5(F1000 Faculty Rev):389 https://doi.org/10.12688/f1000research.7506.1 


\section{Introduction}

Down syndrome (DS) is the most common neurodevelopmental disorder of known genetic cause, with an incidence of between 1:750 and 1:1000 live births ${ }^{1,2}$. The syndrome has been extensively described at the group level, downplaying individual variation and treating DS as a homogeneous group. So, why do we argue in this paper that individual differences across DS at all levels-genetic, cellular, neural, cognitive, behavioral, and environmental- really matter? Our argument is that, in the context of significant increases in DS life expectancy ${ }^{3,4}$, a focus on individual differences in trisomy 21 constitutes one of the best approaches for exploring genotype/phenotype relations in DS and for identifying risk and protective factors for Alzheimer's disease (AD).

DS has usually been described simply as arising from an extra copy of chromosome 21 and presenting with characteristic features including facial dysmorphology, a proportionally large tongue, low muscle tone, short stature, and intellectual disability. Associated conditions may include obstructive sleep apnea, as well as visual and hearing problems. Receptive language usually outstrips language production, spatial memory is thought to be better than verbal memory, and global processing is deemed to be superior to local processing. In adulthood, DS presents with accelerated aging and an increased likelihood of developing AD. The DS brain has been typically described as developing relatively normally during the first few months postnatally ${ }^{5}$, after which growth slows, with cortical areas being particularly reduced ${ }^{6}$.

Yet underlying these group-level accounts are large individual differences at every level of description. We start with a consideration of individual differences in the genetics of DS and go on to examine studies of DS cell biology. We focus next on the broad individual differences in the DS brain, which recent studies have now identified as occurring as early as during fetal development. We go on to explore briefly some of the widespread individual differences in cognitive outcomes in DS, particularly with respect to language and memory, and challenge assumptions that individuals with DS are global rather than local processors ${ }^{7}$. In the following section, we argue that individual differences in sleep patterns in DS are likely to be an important contributor to the differences in language, memory, and AD outcome. We then look briefly at mouse models of DS and AD. We finally conclude that a focus on individual differences at every level across the syndrome is likely to yield deeper insights into genotype/phenotype associations.

\section{Individual differences in Down syndrome genetics}

The most common cause of DS is the additional copy of an entire chromosome 21 . In $~ 88 \%$ of cases, the extra copy is maternally derived, through an error in cell division called non-disjunction. The extra chromosomal content can occur through different mechanisms and at different points during the formation of germ cells. Non-disjunction ${ }^{8}$ can arise during meiosis I ( $65 \%$ maternal; $~ 3 \%$ paternal), during meiosis II ( $23 \%$ maternal; $\sim 5 \%$ paternal), or from a mitotic error $(\sim 3 \%)$. DS can also occur when only a segment of chromosome 21 has three copies (partial trisomy) ${ }^{9}$ or when the whole chromosome is triplicated but only a proportion of the cells are trisomic (mosaicism) with other cells being normal. Mosaicism is found in $\sim 1.3-5 \%$ of cases $^{10}$, but it is possible that mosaicism occurs more frequently, the low percentage being due to ascertainment bias, especially in cases with low-level mosaicism. Further genetic differences can be introduced by variation in the amount of crossover during meiosis I. Research on parental origin or the mechanism of mosaicism is currently sparse, making it difficult to identify the main mechanism. While mosaicism has sometimes been claimed to yield a milder cognitive phenotype ${ }^{9,11}$, data addressing this are very sparse and, where they do exist, the degree of mosaicism does not correlate with phenotypic severity. Interestingly, though, mosaicism provides an excellent opportunity to study phenotypic differences, since disomic and trisomic cell lines derived from mosaics only differ in the extra chromosome $21^{12}$.

Translocation is another mechanism yielding DS, whereby some of the genetic material from chromosome 21 , usually from the long arm, is moved to chromosome 14 or 22 , or from the long to the short arm of chromosome 21 . Translocation occurs in some $4 \%$ of $\operatorname{cases}^{2,13-15}$.

These multiple origins of DS need to be taken into account when considering differences between individuals with trisomy 21 . Additionally, individual differences exist on other chromosomes. The euploid population, while free from gross chromosomal abnormalities, is nonetheless genetically different from one another, due to copy number variations (CNVs), single nucleotide polymorphisms (SNPs), and de novo mutations. Such differences also apply to people with DS, of course, who have many of these variants in addition to their extra copy of all or part of chromosome 21.

With full trisomy, intuitively it might be assumed that expression levels of triplicated genes are 1.5-fold that of the euploid population. However, this is not so. Gene expression is differentially regulated in different tissues, and each gene is subject to the potential of feedback control of expression levels. One recent study of whole genome expression in fibroblasts and lymphoblasts suggested that only a small majority of genes were over-expressed in the range predicted by gene dosage. In contrast, about a quarter showed no difference in expression between DS and diploid cells, and another quarter had intermediate expression ${ }^{16}$. In a second study, also in lymphoblastoid cells, only $22 \%$ of the genes analyzed on chromosome 21 were actually over-expressed 1.5 -fold ${ }^{17}$. In this second study, a few were significantly more amplified $(\sim 7 \%)$, whereas, despite the three copies, many $(>1 / 2)$ turned out to have near normal levels of expression, presumably due to compensatory mechanisms. It must be remembered that these studies were carried out in cell lines; the results may therefore not reflect the gene expression profiles of the cells from which they were derived and certainly will not represent the expression levels in other tissues. Interestingly, both of these cell studies additionally reported a considerable amount of inter-individual differences in gene expression. Expression studies are notoriously inconsistent. Nonetheless, however tentative the findings of the above two studies, it is clear that we cannot take for granted that an extra copy of chromosome 21 will result in a 1.5-fold increase in the level of gene expression. How irregular expression levels of triplicated genes on chromosome 21 (particularly those that may vary substantially between trisomic individuals), coupled with the heterogeneous origins, influence the DS neurocognitive phenotype remains an open but critical question. 
Whilst the expression and role of individual genes are undoubtedly important, the genome-wide implications of trisomy 21 are too often neglected. Functionally, genes sit in a complex biological network. The breadth of influence of genes varies, but those involved in epigenetic mechanisms warrant special attention. Epigenetic mechanisms, including DNA methylation and post-translational histone modifications, contribute substantially to the regulation of gene expression across the genome, and so the effects of changes in epigenetic gene dosage are far-reaching. There are at least 11 genes and multiple microRNAs (miRNAs) on chromosome 21 that are involved in epigenetic mechanisms ${ }^{18}$, including DNMT3L (a DNA methyltransferase), DYRK1A (a kinase), and H2AFZP (a histone variant). Relatively little research has gone into epigenetic processes in trisomy 21, although some studies indicate that people with DS have different DNA methylation from the euploid population ${ }^{19}$. As mentioned above, in some of these genes, expression levels may vary between individuals (such as $B R W D 1$, a transcriptional regulator). Trisomy 21 causes major disturbances in the level, activity, and subcellular localization of two major non-HSA21 transcription factors: $N F A T^{20}$ and NRSF/REST ${ }^{21,22}$. Both of these control the spatiotemporal expression patterns of thousands of downstream target genes, many of which are also transcription factors, generating a whole new layer of complexity. Individual differences in epigenetic regulation can of course also occur on genes not otherwise involved with chromosome 21 , yielding potentially even wider individual differences in the mosaic DS population and those with DS arising from translocation.

One of the reasons why individuals with DS are at higher risk for $\mathrm{AD}$ than the general population is that the amyloid precursor protein $(A P P)$ gene, implicated in the brain pathology of $\mathrm{AD}$, lies on chromosome 21. Individuals with a translocation below the APP gene (i.e. without APP triplication) get DS but not AD. A number of genes that are functionally linked to $A P P$ are dysregulated in the DS brain, including BACE2, APOE, CLU, PSEN1, PSEN2, and $M A P T^{22}$. While amyloid pathology is necessary, triplication of APP alone is not sufficient to cause AD. Whereas many people with DS present with dementia in their 30s, even by age 70 or 80 some adults with DS do not have dementia despite their significant plaque pathology 24,25 .

Genes on other chromosomes also play an important role in AD and here, too, individual differences exist. The apolipoprotein gene $(A P O E)$ on chromosome 19, also implicated in $\mathrm{AD}$, harbors common variants: $\varepsilon 2$, considered protective for $\mathrm{AD}(\sim 7 \%$ of the general population); $\varepsilon 3$, the most common allele ( $79 \%$ frequency), neutral regarding $\mathrm{AD}$ risk; and $\varepsilon 4$ ( $\sim 14 \%$ frequency), thought to harbor the greatest risk for $\mathrm{AD}$, particularly in carriers of two $\varepsilon 4$ alleles. APOE variants modulate the age of onset of $\mathrm{AD}$ in $\mathrm{DS}^{26}$. Interestingly, the distribution of the APOE polymorphisms differs across ethnicities, the above figures holding for Caucasians.

The effects of these $A P O E$ allelic differences are detectable early in life. A recent study of euploid babies between 2 and 25 months of age showed that those who carried the $\varepsilon 4$ variant differed from non-carriers in their rate of myelin development, with $\varepsilon 4$ carriers showing decreased growth in the mid and posterior brain regions ${ }^{27}$. Similar allelic differences and their neural repercussions are likely also to occur in children with DS, impacting on other individual differences.

Other genes, e.g. DYRKIA and RCAN1, located on chromosome 21 , have been shown to be functionally important in the pathogenesis of DS and AD when expression is increased ${ }^{28,29}$. Individual ethnic differences also matter. Indeed, the common variants of these genes are not significantly associated with AD in Caucasians, but there is some suggestion of an association of the RCAN1 polymorphism in a small Chinese cohort ${ }^{30}$. Other research has suggested that $B A C E 2$ alleles, also located on chromosome 21, are important in $\mathrm{AD}$, also affecting the age of dementia onset in $\mathrm{DS}^{31,32}$.

\section{Individual differences in Down syndrome cell biology}

The advent of human induced pluripotent stem cells (iPSCs) has added an exciting new tool for understanding individual differences in DS and their relationship to $\mathrm{AD}^{12,33}$. Shi et al. ${ }^{33}$ found that cortical neurons generated from iPSCs and embryonic stem cells from patients with DS developed AD pathologies in the form of insoluble intracellular and extracellular amyloid aggregates over months in culture, rather than years in vivo. Hyperphosphorylated tau protein, a hallmark of $\mathrm{AD}$, was also localized to cell bodies and dendrites in iPS-derived cortical neurons from the patients with $\mathrm{DS}$, recapitulating later stages of the AD pathogenic process. Interestingly, the same research group showed growth of amyloid- $\beta$ plaques in iPSCs grown from tissue from a DS infant as young as 17 months $^{33}$, attesting to the developmental nature of the brain pathology. Furthermore, an isogenic iPSC model of DS derived from a 16 year old with mosaic $\mathrm{DS}^{12}$ recapitulated these AD-related phenotypes and demonstrated that neurons from trisomy 21 iPSCs accumulate DNA double-strand breaks much faster than those from isogenic euploid controls. It is currently not known whether, but it is assumed that, such accumulated DNA damage is randomly distributed in the genome and as such may increase the variability of pathological phenotypes on the cellular level ${ }^{12}$.

\section{Individual differences in Down syndrome brains}

As mentioned, it used to be thought that the DS brain developed relatively normally throughout fetal life and during the first months postnatally ${ }^{5}$. This assumption has turned out to be incorrect. New studies reveal that DS prenatal brain size is only relatively normal until about 20-24 weeks gestation, after which individual differences in fetal brain development emerge (unpublished data, Rutherford \& Patkee 2015). Some DS brains show reduced volume of the hippocampus, cerebellum, and occipital-frontal areas already during fetal life. In some DS brains, there is initially more or less normal dendritic formation and arborization, but this is followed by a stagnation in the developmental process; subsequently dendrites increase neither in number nor in complexity as the DS fetus develops ${ }^{34}$. At birth, many DS brains already have smaller dendritic arborization ${ }^{35-37}$ and fewer synapses ${ }^{38,39}$, likely to contribute to the reduced functional brain connectivity found in many newborns with $\mathrm{DS}^{40}$. 
Despite large individual differences, some DS brains are difficult to distinguish from the neurotypical case during fetal development (unpublished data, Rutherford \& Patkee 2015), but the neural phenotype becomes progressively more pronounced in DS as development proceeds, with increasing dissociations between cortical thickness (increased) and surface area (reduced) in, for example, frontal and temporal regions ${ }^{41}$. However, yet again, individual differences are apparent, particularly in the early stages of development. In other words, individual differences at both the structural and the functional levels can start very early in the DS developmental trajectory, subsequently yielding large individual differences in functional connectivity, which correlate, for instance, with communication skills ${ }^{42}$. Finally, $40 \%$ of infants with DS are born with congenital heart disease, which also potentially compromises blood flow to the brain, but even those without heart problems ultimately go on to develop atypical brains ${ }^{43}$.

Examining the brains of adults with DS, MRI studies have demonstrated that the size of the cerebellum, hippocampus, and cortex is significantly smaller than in the neurotypical case, while basal ganglia are similar in size and ventricles are enlarged ${ }^{44}$. Individual differences are particularly apparent when comparing DS adults with or without dementia; the former have reduced ventricular, hippocampal, and caudate volumes, as well as increased levels of peripheral cerebrospinal fluid (CSF), compared to those without dementia ${ }^{45}$. The differences between those with and without dementia can start very early. In vivo studies of children with DS identified plaques in DS brains as early as 8 years of age ${ }^{46}$. To be noted, however, were the large individual differences, with some DS brains having no plaques until early adulthood.

\section{Individual differences in Down syndrome cognition}

Atypical cognitive phenotypes in DS become increasingly evident across the lifespan ${ }^{47}$. Children under 12 months old often show few cognitive differences from neurotypical controls on standardized tests (due, perhaps, to a lack of sensitivity to detect them) but, as they get older, the rate of intellectual development in DS slows considerably.

Most of the cognitive studies of DS have reported group data, comparing DS either to neurotypical controls ${ }^{48-50}$ or to other neurodevelopmental disorders ${ }^{51-56}$. Yet hidden within these group data are wide individual differences, particularly in IQ scores, language, and other measures ${ }^{57-61}$. And these differences start early; in our recent research on infants/toddlers with DS, standard composite scores (not dissimilar to IQ scores) on the Mullen Scales of Early Learning $^{62}$ show significant variation, with many young children scoring at floor, while some others' scores reach the 80 s to 90 s. In adults with DS, some $50 \%$ have IQs at floor, whereas a few have IQs in the 70s or above ${ }^{63}$. The significance of these individual differences is being increasingly recognized, such that we are developing new task batteries to detect the wide range of scores more precisely ${ }^{64,65}$.

Individual differences in basic-level processes like reaction time, attention, and memory impact on developmental trajectories over time. For example, the DS memory profile is associated with poor short-term verbal memory ${ }^{66}$ and poor long-term visual memory ${ }^{54}$.
In contrast, implicit memory is thought to be comparable to agematched neurotypicals ${ }^{49}$. However, again these observations are based on group data, with individual memory profiles being significantly more variable ${ }^{67}$. In Vicari et al.' ${ }^{49}$ paper, implicit memorymeasured by reaction time-was on average longer in DS than in neurotypicals, but the standard deviations were almost three times larger in the DS group. This might mean that some individuals with DS had shorter reaction times even than the controls. Such individual differences are camouflaged when reporting average group data yet are critical to fully understand the DS phenotype.

As mentioned in the introduction, DS is often described as having better visuospatial memory than verbal memory, as well as better global processing than local processing. First, individual differences are large, and, second, in-depth probing of processing across modalities (visual/auditory) and across levels of processing (low-level perceptual processes vs. high-level) yielded no consistent global processing style ${ }^{7}$.

Another domain that yields wide individual differences in DS is language - for some, considered the domain of greatest vulnerability in the syndrome ${ }^{59,68}$. This claim is made from comparisons of children with DS to neurotypicals at the group level. A very different picture emerges when individual differences are taken into consideration. For example, Zampini and D'Odorico ${ }^{69}$ reported that, in their longitudinal study of DS vocabulary acquisition, at 36 months the lowest scoring child was nonverbal, while the highest scoring child was close to the normal range, producing 243 words. When the same children were assessed 6 months later, the nonverbal child remained nonverbal, whereas the one with the most developed language had doubled production to nearly 500 words. This highlights the wide individual differences in DS language development, which persists into adulthood ${ }^{70}$.

However, in order to fully understand how those with DS develop, it is crucial to study how individual differences in underlying processes (e.g., auditory/visual attention, motor control) constrain higher-level cognitive outcomes (e.g. language). For example, there is much greater variability in the timing of the onset of muscle activation in DS than in neurotypicals ${ }^{71,72}$, such that distal muscles are often activated before proximal muscles. It is possible, then, that the variability in underlying mechanisms, such as muscle activation, becomes subsequently measurable as differences in DS cognitive abilities.

Another example from our recent work on very young children with DS reveals that individual differences in an electrophysiological measure of auditory attention in toddlers with DS are associated with differences in language ability ${ }^{73}$. On average, the toddlers with DS oriented to changes in pitch more than changes in speech, but wide individual differences emerged: toddlers with DS who oriented more to changes in pitch had worse expressive language, suggesting that those who rely excessively on global properties of sounds (e.g., tone, changes in pitch) are not using an optimal strategy for language learning. As a group, the toddlers were also slow at disengaging attention from visual stimuli, but again individual differences indicated that those who were particularly poor at disengaging visual attention had worse language ability. 
Thus, individual differences in both visual and auditory attention predict language differences in the DS children, indicating that small differences in attention during very early development impact the subsequent development of other higher-level domains like language $\mathrm{e}^{74}$.

\section{Individual differences in Down syndrome sleep}

Sleep has a crucial function in ensuring metabolic homeostasis and the clearance of toxins like $\beta$-amyloid from the brain. Using real-time assessments of tetramethylammonium diffusion and two-photon imaging in live mice, Xie and colleagues ${ }^{75}$ showed that deep sleep is associated with a $60 \%$ increase in the interstitial space, resulting in a striking increase in convective exchange of CSF with interstitial fluid. The researchers showed that convective fluxes of interstitial fluid increase the rate of $\beta$-amyloid clearance during sleep. The restorative function of sleep may thus be a consequence of the enhanced removal of potentially neurotoxic waste products that accumulate in the central nervous system when awake. Therefore, if individuals with DS show differences in their sleep architecture, such $\beta$-amyloid clearance may be differentially compromised.

Indeed, there is an increased risk of sleep fragmentation in DS because of obstructive sleep apnea in this population ${ }^{76-79}$. Edgin and collaborators found that children with DS with obstructive sleep apnea syndrome had impaired executive function as well as verbal IQs nine points lower than those without apnea ${ }^{79}$. Even in the euploid population, poor sleep quality, particularly sleep fragmentation, is a strong predictor of lower academic performance ${ }^{80}$, reduced attentional capacities ${ }^{81}$, poor executive function ${ }^{82}$, and challenging behaviors ${ }^{83}$. As far as young adults with DS are concerned, our ongoing work suggests that 16-35 year olds with disturbed sleep have poorer cognitive scores, lower adaptive behavior scores, and poorer verbal fluency ${ }^{65}$. Again, individual differences in sleep patterns start early. Our current work with infants and toddlers with DS is revealing correlations between increased sleep fragmentation (not duration) and decreased memory, language, and attention shifts ${ }^{84}$. If amyloid clearance is subject to wide individual differences in DS due to varying levels of sleep fragmentation, this may be a clue to one of the reasons why some individuals go on to present with dementia and others do not. It is therefore possible that individual differences in sleep patterns in the DS population across the lifespan, together with other factors, impact on risk and protective factors for $\mathrm{AD}$.

\section{Individual differences in Down syndrome animal models}

Murine models of DS and of AD-DS exist, based on ortholog genes to human chromosome 21, which are located on chromosomes 10,16 , and 17 in the mouse ${ }^{85,86}$. Most are kept on inbred, identical genetic backgrounds and are used to identify genes associated with neurobehavioral traits. Although rarely reported, it is clear that, even in inbred strains, phenotypic variability occurs in terms of rate of development, disease, and behavioral traits. Using prenatal and postnatal cross-fostering methods, several studies have shown that these individual differences stem from environmental factors, such as amount of maternal licking/grooming, i.e. epigenetic programming by maternal behavior ${ }^{87}$, rather than genetic differences between offspring ${ }^{88-90}$. It is becoming increasingly likely that individual epigenetic changes arising from experience of a parent can be transmitted to their offspring and to future generations ${ }^{91}$. Variations in rat maternal care have been shown to affect hippocampal function as well as performance on hippocampal-dependent learning and memory tests in the offspring ${ }^{88}$. There is every reason to believe that mouse models of DS would reveal similar effects (see discussion in 86). For instance, transgenic mice overexpressing Dyrk1A, a candidate gene on chromosome 21, show serious alterations in adult neurogenesis, including reduced cell proliferation rate, altered cell cycle progression, and reduced cell cycle exit, leading to premature migration, differentiation, and reduced survival of newly born cells. In addition, less proportion of newborn hippocampal TgDyrk $1 A$ neurons are activated upon learning, suggesting reduced integration in learning circuits. A number of these alterations can be normalized both pharmacologically and by environmental stimulation $^{92}$.

\section{Concluding thoughts}

The fact that DS presents with so many individual differences, at so many levels, clearly indicates that thinking of DS merely in terms of an extra copy of chromosome 21 would be simplistic. Many other genetic, epigenetic, and environmental factors play a role in how the DS phenotype expresses itself in each individual. Whereas mosaicism has sometimes been claimed to yield a milder cognitive phenotype, albeit with few data to support the claim, it remains unknown whether genetic differences in the original, individual causes of DS lead to corresponding differences in neurocognitive outcomes. Numerous other interacting factors are likely to contribute to individual differences and cognitive-level outcomes in DS, including early neural development, sleep, attention, memory, and the environment.

It is also important to note that having a neurodevelopmental disorder like DS actually changes the environment (both social and physical) in which infants and children develop, in terms of parental expectations and their interactions with their child ${ }^{61,93}$. A more complex, dynamic view is thus required of how individual differences in the child's social, cultural, and physical environments interact with individual differences in genetics and epigenetics.

One thing is clear: scientists cannot consider those with DS as a homogeneous group. Consideration of individual variation at multiple levels opens a series of new questions raised in this review that remained hidden in studies at the DS group level. Thus, scientists must take on board the crucial importance of individual differences if we are to understand fully the relationships between genotype and the emerging phenotype, and why some individuals with DS do not go on to present with dementia despite their brain histopathology. Moreover, it is becoming increasingly clear that Alzheimer's dementia is a developmental disease $\mathrm{e}^{74}$ and that trisomy 21 is a particularly good model for understanding many of the complexities of that developmental process across the lifespan.

$\begin{array}{ll}\text { Abbreviations } \\ \text { AD } & \text { Alzheimer's disease } \\ \text { APOE } & \text { Apolipoprotein } \\ \text { APP } & \text { Amyloid precursor protein } \\ \text { CSF } & \text { Cerebrospinal fluid }\end{array}$


DS

Down syndrome

iPSCs Induced pluripotent stem cells

\section{Competing interests}

All the authors declare that the writing of this paper took place in the absence of any commercial or financial relationships that could be construed as a potential conflict of interest.
Grant information

All the authors of this paper are funded by Wellcome Trust Strategic Grant No. 098330/Z/12/Z conferred upon The LonDownS Consortium UK. Dean Nizetic is funded also by the Lee Kong Chian School of Medicine, Nanyang Technological UniversitySingapore Start-up Grant.

I confirm that the funders had no role in study design, data collection and analysis, decision to publish, or preparation of the manuscript.
1. Parker SE, Mai CT, Canfield MA, et al.: Updated National Birth Prevalence estimates for selected birth defects in the United States, 2004-2006. Birth Defects Res A Clin Mol Teratol. 2010; 88(12): 1008-1016.

PubMed Abstract | Publisher Full Text

2. Morris JK, Alberman E, Mutton D, et al:: Cytogenetic and epidemiological findings in Down syndrome: England and Wales 1989-2009. Am J Med Genet $A$ 2012; 158A(5): 1151-1157. PubMed Abstract

3. Yang Q, Rasmussen SA, Friedman JM: Mortality associated with Down's syndrome in the USA from 1983 to 1997: a population-based study. Lancet. 2002; 359(9311): 1019-1025. PubMed Abstract | Publisher Full Text

4. Bittles AH, Glasson EJ: Clinical, social, and ethical implications of changing life expectancy in Down syndrome. Dev Med Child Neurol. 2004; 46(4): 282-286. PubMed Abstract | Publisher Full Text

5. Wisniewski KE, Schmidt-Sidor B: Postnatal delay of myelin formation in brains from Down syndrome infants and children. Clin Neuropathol. 1989; 8(2): 55-62. PubMed Abstract

6. White NS, Alkire MT, Haier RJ: A voxel-based morphometric study of nondemented adults with Down Syndrome. Neuroimage. 2003; 20(1): 393-403. PubMed Abstract | Publisher Full Text

7. D'Souza D, Booth R, Connolly M, et al:: Rethinking the concepts of 'local or global processors': evidence from Williams syndrome, Down syndrome, and Autism Spectrum Disorders. Dev Sci. 2015.

PubMed Abstract | Publisher Full Text | Free Full Text

8. Hassold T, Hunt P: To err (meiotically) is human: the genesis of human aneuploidy. Nat Rev Genet. 2001; 2(4): 280-291. PubMed Abstract | Publisher Full Text

9. Korbel JO, Tirosh-Wagner T, Urban AE, et al:: The genetic architecture of Down syndrome phenotypes revealed by high-resolution analysis of human segmental trisomies. Proc Natl Acad Sci U S A. 2009; 106(29): 12031-12036. PubMed Abstract | Publisher Full Text | Free Full Text

10. Papavassiliou $\mathrm{P}$, Charalsawadi $\mathrm{C}$, Rafferty $\mathrm{K}$, et al:: Mosaicism for trisomy 21: a review. Am J Med Genet A. 2015; 167A(1): 26-39. PubMed Abstract | Publisher Full Tex

11. Zhao W, Chen F, Wu M, et al:: Postnatal Identification of Trisomy 21: An Overview of 7,133 Postnatal Trisomy 21 Cases Identified in a Diagnostic Reference Laboratory in China. PLoS One. 2015; 10(7): e0133151. PubMed Abstract | Publisher Full Text | Free Full Text

12. Murray A, Letourneau A, Canzonetta C, et al:: Brief report: isogenic induced pluripotent stem cell lines from an adult with mosaic Down syndrome model accelerated neuronal ageing and neurodegeneration. Stem Cells. 2015; 33(6): 2077-2084.

PubMed Abstract | Publisher Full Text | Free Full Text

13. Hernandez D, Fisher EM: Down syndrome genetics: unravelling a multifactoria disorder. Hum Mol Genet. 1996; 5(Spec No): 1411-1416. PubMed Abstract

14. Flores-Ramírez F, Palacios-Guerrero C, García-Delgado C, et al.: Cytogenetic profile in 1,921 cases of trisomy 21 syndrome. Arch Med Res. 2015; 46(6): 484-489. PubMed Abstract | Publisher Full Text

15. Sherman SL, Freeman SB, Allen EG, et al:: Risk factors for nondisjunction of trisomy 21. Cytogenet Genome Res. 2005; 111(3-4): 273-280. PubMed Abstract | Publisher Full Text

16. Prandini $P$, Deutsch $S$, Lyle $R$, et al: Natural gene-expression variation in Down syndrome modulates the outcome of gene-dosage imbalance. Am J Hum Genet. 2007; 81(2): 252-263. PubMed Abstract | Publisher Full Text | Free Full Text

17. F Ait Yahya-Graison E, Aubert J, Dauphinot L, et al:: Classification of human chromosome 21 gene-expression variations in Down syndrome: impact on disease phenotypes. Am J Hum Genet. 2007, 81(3): 475-91. PubMed Abstract | Publisher Full Text | Free Full Text | F1000 Recommendation

18. Dekker AD, De Deyn PP, Rots MG: Epigenetics: the neglected key to minimize learning and memory deficits in Down syndrome. Neurosci Biobehav Rev. 2014; 45: 72-84.

PubMed Abstract | Publisher Full Text

19. Jones MJ, Farré P, McEwen LM, et al:: Distinct DNA methylation patterns of cognitive impairment and trisomy 21 in Down syndrome. BMC Med Genomics. 2013; $6: 58$.

PubMed Abstract | Publisher Full Text | Free Full Text

20. F Arron JR, Winslow MM, Polleri A, et al.: NFAT dysregulation by increased dosage of DSCR1 and DYRK1A on chromosome 21. Nature. 2006; 441(7093): $595-600$.

PubMed Abstract | Publisher Full Text | F1000 Recommendation

21. Canzonetta C, Mulligan C, Deutsch S, et al.: DYRK1A-dosage imbalance perturbs NRSF/REST levels, deregulating pluripotency and embryonic stem cell fate in Down syndrome. Am J Hum Genet. 2008; 83(3): 388-400.

PubMed Abstract | Publisher Full Text | Free Full Text

22. Lepagnol-Bestel AM, Zvara A, Maussion G, et al.: DYRK1A interacts with the REST/NRSF-SWI/SNF chromatin remodelling complex to deregulate gene clusters involved in the neuronal phenotypic traits of Down syndrome. Hum Mol Genet. 2009; 18(8): 1405-1414.

PubMed Abstract | Publisher Full Text

23. Lockstone HE, Harris LW, Swatton JE, et al:: Gene expression profiling in the adult Down syndrome brain. Genomics. 2007; 90(6): 647-660. PubMed Abstract | Publisher Full Text

24. F Krinsky-McHale SJ, Devenny DA, Gu H, et al:: Successful aging in a 70-year-old man with Down syndrome: a case study. Intellect Dev Disabil. 2008; 46(3): $215-228$.

PubMed Abstract | Publisher Full Text | F1000 Recommendation

25. F Ghezzo A, Salvioli S, Solimando MC, et al.: Age-related changes of adaptive and neuropsychological features in persons with Down Syndrome. PLOS One. 2014; 9(11): e113111.

PubMed Abstract | Publisher Full Text | Free Full Text | F1000 Recommendation

26. F Prasher VP, Sajith SG, Rees SD, et al:: Significant effect of APOE epsilon 4 genotype on the risk of dementia in Alzheimer's disease and mortality in persons with Down syndrome. Int J Geriatr Psychiatry. 2008; 23(11): 1134-1140. PubMed Abstract | Publisher Full Text | Free Full Text | F1000 Recommendation

27. F Dean DC 3rd, Jerskey BA, Chen $\mathrm{K}$, et al:: Brain differences in infants at differential genetic risk for late-onset Alzheimer disease: a cross-sectional imaging study. JAMA Neurol. 2014; 71(1): 11-22.

PubMed Abstract | Publisher Full Text | Free Full Text | F1000 Recommendation

28. Abbassi R, Johns TG, Kassiou M, et al:: DYRK1A in neurodegeneration and cancer: Molecular basis and clinical implications. Pharmacol Ther. 2015; 151: 87-98. PubMed Abstract | Publisher Full Text

29. $\mathrm{F}$ Wu $Y$, Deng $Y$, Zhang $S$, et al:: Amyloid- $\beta$ precursor protein facilitates the regulator of calcineurin 1-mediated apoptosis by downregulating proteasome subunit $\alpha$ type- 5 and proteasome subunit $\beta$ type-7. Neurobiol Aging. 2015; 36(1): subunit a t

PublMed Abstract | Publisher Full Text | F1000 Recommendation

30. F Lin KG, Tang M, Guo YB, et al:: Two polymorphisms of RCAN1 gene associated with Alzheimer's disease in the Chinese Han population. East Asian Arch Psychiatry. 2011; 21(2): 79-84. PubMed Abstract | F1000 Recommendation

31. Myllykangas L, Wavrant-De Vrièze F, Polvikoski T, et al.: Chromosome 21 BACE2 haplotype associates with Alzheimer's disease: a two-stage study. J Neurol SCI. 2005; 236(1-2): 17-24.

PubMed Abstract | Publisher Full Text 
32. Mok KY, Jones EL, Hanney M, et al:: Polymorphisms in BACE2 may affect the age of onset Alzheimer's dementia in Down syndrome. Neurobiol Aging. 2014; 35(6): 1513.e1-5.

PubMed Abstract | Publisher Full Text | Free Full Text

33. F Shi Y, Kirwan P, Smith J, et al:: A human stem cell model of early Alzheimer's disease pathology in Down syndrome. Sci Trans/ Med. 2012; 4(124): 124ra29. PubMed Abstract | Publisher Full Text | Free Full Text | F1000 Recommendation

34. Mrak RE, Griffin WS: Trisomy 21 and the brain. J Neuropathol Exp Neurol. 2004; 63(7): 679-685.

PubMed Abstract | Publisher Full Text | Free Full Text

35. Becker LE, Armstrong DL, Chan F: Dendritic atrophy in children with Down's syndrome. Ann Neurol. 1986; 20(4): 520-526.

PubMed Abstract | Publisher Full Text

36. Benavides-Piccione R, Ballesteros-Yáñez I, de Lagrán MM, et al:: On dendrites in Down syndrome and DS murine models: a spiny way to learn. Prog Neurobiol. 2004; 74(2): 111-126.

PubMed Abstract | Publisher Full Text

37. Takashima S, leshima A, Nakamura $\mathrm{H}$, et al:: Dendrites, dementia and the Down syndrome. Brain Dev. 1989; 11(2): 131-133.

PubMed Abstract | Publisher Full Text

38. Petit TL, LeBoutillier JC, Alfano DP, et al.: Synaptic development in the human etus: a morphometric analysis of normal and Down's syndrome neocortex. Exp Neurol. 1984; 83(1): 13-23.

PubMed Abstract | Publisher Full Text

39. Weitzdoerfer R, Dierssen M, Fountoulakis M, et al.: Fetal life in Down syndrome starts with normal neuronal density but impaired dendritic spines and synaptosomal structure. J Neural Transm Suppl. 2001; (61): 59-70. PubMed Abstract | Publisher Full Text

40. Imai M, Watanabe $\mathrm{H}$, Yasui $\mathrm{K}$, et al:: Functional connectivity of the cortex of term and preterm infants and infants with Down's syndrome. Neuroimage. 2014; 85(Pt 1): 272-278.

PubMed Abstract | Publisher Full Text

41. Lee NR, Adeyemi El, Lin A, et al.: Dissociations in Cortical Morphometry in Youth with Down Syndrome: Evidence for Reduced Surface Area but Increased Thickness. Cereb Cortex. 2015. pii: bhv107. PubMed Abstract | Publisher Full Text

42. F Pujol J, del Hoyo L, Blanco-Hinojo L, et al:: Anomalous brain functional connectivity contributing to poor adaptive behavior in Down syndrome. Cortex. 2015; 64: 148-156.

PubMed Abstract | Publisher Full Text | F1000 Recommendation

43. Day JJ, Sweatt JD: Cognitive neuroepigenetics: a role for epigenetic mechanisms in learning and memory. Neurobiol Learn Mem. 2011; 96(1): 2-12. PubMed Abstract | Publisher Full Text | Free Full Text

44. Strydom A, Hassiotis A, Walker Z: Magnetic resonance imaging in people with Down's syndrome and Alzheimer's disease. J Intellect Disabil Res. 2004; 48(Pt 8): 769-770.

PubMed Abstract | Publisher Full Text

45. F Beacher F, Daly E, Simmons A, et al:: Alzheimer's disease and Down's syndrome: an in vivo MRI study. Psychol Med. 2009; 39(4): 675-684. PubMed Abstract | Publisher Full Text | F1000 Recommendation

46. F Leverenz JB, Raskind MA: Early amyloid deposition in the medial temporal lobe of young Down syndrome patients: a regional quantitative analysis. Exp Neurol. 1998; 150(2): 296-304.

PubMed Abstract | Publisher Full Text | F1000 Recommendation

47. Chapman RS, Hesketh LJ: Behavioral phenotype of individuals with Down syndrome. Ment Retard Dev Disabil Res Rev. 2000; 6(2): 84-95. PubMed Abstract | Publisher Full Text

48. Raitano Lee N, Pennington BF, Keenan JM: Verbal short-term memory deficits in Down syndrome: phonological, semantic, or both? J Neurodev Disord. 2010; 2(1): 9-25.

PubMed Abstract | Publisher Full Text | Free Full Text

49. F Vicari S, Bellucci S, Carlesimo GA: Implicit and explicit memory: a functional dissociation in persons with Down syndrome. Neuropsychologia. 2000; 38(3): 240-251.

PubMed Abstract | Publisher Full Text | F1000 Recommendation

50. Wright I, Lewis V, Collis GM: Imitation and representational development in young children with Down syndrome. Br J Dev Psychol. 2006; 24(2): 429-450. Publisher Full Text

51. Annaz D, Karmiloff-Smith A, Johnson MH, et al:: A cross-syndrome study of the development of holistic face recognition in children with autism, Down syndrome, and Williams syndrome. J Exp Child Psychol. 2009; 102(4): 456-486. PubMed Abstract | Publisher Full Text

52. Brown JH, Johnson MH, Paterson SJ, et al: Spatial representation and attention in toddlers with Williams syndrome and Down syndrome. Neuropsychologia. 2003; 41(8): 1037-1046.

PubMed Abstract | Publisher Full Text

53. Dimitriou D, Leonard HC, Karmiloff-Smith A, et al:: Atypical development of configural face recognition in children with autism, Down syndrome and Williams syndrome. J Intellect Disabil Res. 2015; 59(5): 422-438. PubMed Abstract | Publisher Full Text

54. Jarrold C, Baddeley $A D$, Phillips C: Long-term memory for verbal and visua information in Down syndrome and Williams syndrome: performance on the
Doors and People test. Cortex. 2007; 43(2): 233-247.

PubMed Abstract | Publisher Full Text

55. Karmiloff-Smith A, D'Souza D, Dekker TM, et al:: Genetic and environmenta vulnerabilities in children with neurodevelopmental disorders. Proc Natl Acad Sci U S A. 2012; 109(Suppl 2): 17261-17265.

PubMed Abstract | Publisher Full Text | Free Full Text

56. Karmiloff-Smith A, Brown JH, Grice S, et al:: Dethroning the myth: cognitive dissociations and innate modularity in Williams syndrome. Dev Neuropsychol. 2003; 23(1-2): 227-242.

PubMed Abstract | Publisher Full Text

57. Pennington BF, Moon J, Edgin J, et al:: The neuropsychology of Down syndrome: evidence for hippocampal dysfunction. Child Dev. 2003; 74(1): $75-93$.

PubMed Abstract | Publisher Full Text

58. Ann L, Brahm N: Special Teaching For Special Children? A Pedagogies for Inclusion. McGraw-Hill Education (UK), 2005.

Reference Source

59. Abbeduto L, Warren SF, Conners FA: Language development in Down syndrome: from the prelinguistic period to the acquisition of literacy. Ment Retard Dev Disabil Res Rev. 2007; 13(3): 247-261.

PubMed Abstract | Publisher Full Text

60. Chapman RS: In (ed. Retardation, B.-I. R. of R. in M.). Academic Press, 2003; 27: 1-34.

61. Cebula KR, Moore DG, Wishart JG: Social cognition in children with Down's syndrome: challenges to research and theory building. J Intellect Disabil Res. 2010; 54(2): 113-134.

PubMed Abstract | Publisher Full Text

62. Mullen EM: Mullen scales of early learning. American Guidance Service, 1995

63. F Glenn S, Cunningham C: Performance of young people with Down syndrome on the Leiter-R and British picture vocabulary scales. J Intellect Disabil Res. 2005; 49(Pt 4): 239-244.

PubMed Abstract | Publisher Full Text | F1000 Recommendation

64. Startin C, Rodger E, Fodor-Wynne L, et al:: The Cognitive Scale for Down Syndrome (CSDS). Submitted.

65. Startin C, Hamburg S, Hithersay R, et al:: The London Down Syndrome Consortium (LonDownS): protocol for cognitive assessments. Prep.

66. Jarrold C, Baddeley AD, Phillips CE: Verbal short-term memory in Down syndrome: a problem of memory, audition, or speech? J Speech Lang Hear Res. 2002; 45(3): 531-544.

PubMed Abstract | Publisher Full Text

67. Edgin JO, Pennington BF, Mervis CB: Neuropsychological components of intellectual disability: the contributions of immediate, working, and associative memory. J Intellect Disabil Res. 2010; 54(5): 406-417.

PubMed Abstract | Publisher Full Text | Free Full Text

68. Fidler DJ, Philofsky A, Hepburn SL, et al:: Nonverbal requesting and problemsolving by toddlers with Down syndrome. Am J Ment Retard. 2005; 110(4): 312-322.

PubMed Abstract | Publisher Full Text | Free Full Text

69. F Zampini L, D'Odorico L: Communicative gestures and vocabulary development in 36-month-old children with Down's syndrome. Int J Lang Commun Disord. 2009; 44(6): 1063-1073.

PubMed Abstract | Publisher Full Text | F1000 Recommendation

70. Nelson LD, Orme D, Osann K, et al:: Neurological changes and emotional functioning in adults with Down Syndrome. J Intellect Disabil Res. 2001; 45(Pt 5): $450-456$.

PubMed Abstract | Publisher Full Text

71. Almeida GL, Corcos DM, Hasan Z: Horizontal-plane arm movements with direction reversals performed by normal individuals and individuals with Down syndrome. J Neurophysiol. 2000; 84(4): 1949-1960. PubMed Abstract

72. Hinnell C, Virji-Babul N: Mental rotation abilities in individuals with Down syndrome--a pilot study. Downs Syndr Res Pract. 2004; 9(1): 12-16. PubMed Abstract

73. D'Souza D, D'Souza H, Johnson MH, et al:: Are early neurophysiological markers of ASD syndrome-specific? A cross-syndrome comparison. Paper presented at the XIX Biennial International Conference on Infant Studies, International Society on Infant Studies, Berlin, Germany. 2014

74. Karmiloff-Smith A: Development itself is the key to understanding developmental disorders. Trends Cogn Sci. 1998; 2(10): 389-398.

PubMed Abstract | Publisher Full Text

75. F Xie L, Kang $\mathrm{H}, \mathrm{Xu} \mathrm{Q}$, et al:: Sleep drives metabolite clearance from the adult brain. Science. 2013; 342(6156): 373-377.

PubMed Abstract | Publisher Full Text | Free Full Text | F1000 Recommendation

76. Diomedi M, Placidi F, Cupini LM, et al:: Cerebral hemodynamic changes in sleep apnea syndrome and effect of continuous positive airway pressure treatment. Neurology. 1998; 51(4): 1051-1056.

PubMed Abstract | Publisher Full Text

77. Dykens EM, Hodapp RM, Evans DW: Profiles and development of adaptive behavior in children with Down syndrome. Am J Ment Retard. 1994; 98(5): 580-587

PubMed Abstract

78. Breslin JH, Edgin JO, Bootzin RR, et al:: Parental report of sleep problems in 
Down syndrome. J Intellect Disabil Res. 2011; 55(11): 1086-1091. PubMed Abstract | Publisher Full Text

79. F Edgin JO, Tooley U, Demara B, et al.: Sleep Disturbance and Expressive Language Development in Preschool-Age Children With Down Syndrome. Child Dev. 2015; 86(6): 1984-1998.

PubMed Abstract | Publisher Full Text | Free Full Text | F1000 Recommendation

80. F Fredriksen K, Rhodes J, Reddy R, et al.: Sleepless in Chicago: tracking the effects of adolescent sleep loss during the middle school years. Child Dev. 2004; 75(1): 84-95

PubMed Abstract | Publisher Full Text | F1000 Recommendation

81. Ashworth A, Hill CM, Karmiloff-Smith A, et al.: Cross syndrome comparison of sleep problems in children with Down syndrome and Williams syndrome. Res Dev Disabil. 2013; 34(5): 1572-1580. PubMed Abstract | Publisher Full Text

82. F Archbold KH, Giordani B, Ruzicka DL, et al:: Cognitive executive dysfunction in children with mild sleep-disordered breathing. Biol Res Nurs. 2004; 5(3): 168-176.

PubMed Abstract | F1000 Recommendation

83. F Lewin DS, Rosen RC, England SJ, et al.: Preliminary evidence of behaviora and cognitive sequelae of obstructive sleep apnea in children. Sleep Med. 2002; 3(1): 5-13.

PubMed Abstract | Publisher Full Text | F1000 Recommendation

84. Massand E, Ball G, Erikkson M, et al:: Sleep fragmentation in infants/toddlers with Down syndrome: Relationships with language, motor abilities and attention. Prep.

85. Dierssen M, Herault $\mathrm{Y}$, Estivill $\mathrm{X}$ : Aneuploidy: from a physiological mechanism of variance to Down syndrome. Physiol Rev. 2009; 89(3): 887-920. PubMed Abstract | Publisher Full Text

86. Choong XY, Tosh JL, Pulford LJ, et al: Dissecting Alzheimer disease in Down syndrome using mouse models. Front Behav Neurosci. 2015; 9: 268. PubMed Abstract | Publisher Full Text | Free Full Text

87. $\mathrm{F}$ Weaver IC, Cervoni N, Champagne FA, et al.: Epigenetic programming by maternal behavior. Nat Neurosci. 2004; 7(8): 847-854. PubMed Abstract | Publisher Full Text | F1000 Recommendation

88. Fish EW, Shahrokh D, Bagot R, et al.: Epigenetic programming of stress responses through variations in maternal care. Ann N Y Acad Sci. 2004; 1036: 167-180. PubMed Abstract | Publisher Full Text

89. F Francis DD, Szegda K, Campbell G, et al:: Epigenetic sources of behavioral differences in mice. Nat Neurosci. 2003; 6(5): 445-446. PubMed Abstract | Publisher Full Text | F1000 Recommendation

90. Crabbe JC, Phillips TJ: Mother nature meets mother nurture. Nat Neurosci. 2003; 6(5): 440-442 PubMed Abstract | Publisher Full Text

91. Bohacek J, Mansuy IM: Molecular insights into transgenerational non-genetic inheritance of acquired behaviours. Nat Rev Genet. 2015; 16(11): 641-652. PubMed Abstract | Publisher Full Text

92. Pons-Espinal M, de Lagran MM, Dierssen M: Functional implications of hippocampal adult neurogenesis in intellectual disabilities. Amino Acids. 2013; 45(1): 113-131. PubMed Abstract | Publisher Full Text

93. Moore DG, Oates JM, Hobson RP, et al:: Cognitive and social factors in the development of infants with Down syndrome. Downs Syndr Res Pract. 2002; 8(2): 43-52.

PubMed Abstract | Publisher Full Text 


\section{Open Peer Review}

\section{Current Peer Review Status:}

\section{Editorial Note on the Review Process}

Faculty Reviews are review articles written by the prestigious Members of Faculty Opinions. The articles are commissioned and peer reviewed before publication to ensure that the final, published version is comprehensive and accessible. The reviewers who approved the final version are listed with their names and affiliations.

\section{The reviewers who approved this article are:}

\section{Version 1}

\section{Jennifer Wishart}

Moray House School of Education, University of Edinburgh, Edinburgh, UK

Competing Interests: No competing interests were disclosed.

\section{Roger H. Reeves}

Department of Physiology and McKusick-Nathans Institute of Genetic Medicine, Johns Hopkins University, Baltimore, MD, USA

Competing Interests: No competing interests were disclosed.

The benefits of publishing with F1000Research:

- Your article is published within days, with no editorial bias

- You can publish traditional articles, null/negative results, case reports, data notes and more

- The peer review process is transparent and collaborative

- Your article is indexed in PubMed after passing peer review

- Dedicated customer support at every stage

For pre-submission enquiries, contact research@f1000.com 